\title{
The growth and yield performances of Groundnut in Sole cropping and intercropped with Okra and Maize in Enugu, South Eastern Nigeria.
}

\author{
Nweke, I. A*, Ijearu. S. I**. and Igili, D.N* \\ 1 Department of Soil Science, Anambra State University, Uli. \\ 2 Department of Agricultural Education Institute of Ecumenical Education Thinker's Corner Enugu, Enugu \\ State. \\ ${ }^{3}$ Department of crop science Anambra State University Uli
}

\begin{abstract}
The growth and yield performances of groundnut in Sole cropping and intercropped with Okra and maize was investigated in field trial at the Thinker's Corner Emene-Nike, Enugu State. The experiment was a Randomized Complete Block Design (RCBD) with four replicates which consisted of Groundnut sole cropping $(S G)$. Groundnut intercropped with Okra (GO), Groundnut intercropped with maize (GM), Groundnut, Maize, Okra intercropped (GMO). Growth and yield parameters such as height, branches, leaflets, flowering and weight of pods (Fruits) were assessed. The result obtained indicated that there were no significant differences $(P=0.05)$ among the treatments in height, branches and leaflets. The Fruits weight and days to 50\% flowering showed significant differences among the treatments. Groundnut on Sole cropping yield better with a Value $28.75 \mathrm{gm}$ and performed competitively better than the one intercropped with either Okra or maize as well as the one intercropped with maize and Okra in the parameters measured. Groundnut intercropped with Okra however, performed relatively better than the Groundnut/Maize intercrop and Groundnut/Maize/Okra intercrop. While Groundnut intercropped with Maize and Okra performed poorly in all the parameters assessed in this study.
\end{abstract}

Key words: Sole cropping, Inter cropping, Groundnut, Okra, Maize.

\section{Introduction.}

The importance of groundnut in the economic development and social well being of people in particular and Nigeria in general cannot be over emphasized. Groundnut is very important to both man and his animals, and the high oil and protein content in the groundnut make it an important food crop (Encyclopedia of Agricultural Science 1994). Okra (Abelmoschus esculentus (L) Moench) is cultivated as a vegetable crop for its mineral and Vitamins Supply to the body. Okra is known to posses some medicinal properties. The leaves may be consumed as pot herbs (Ogbaji 2002).

Maize and Okra with limited groundnut mixture are identified as common mixture associated with traditional farming system in the South Eastern part of Nigeria. Crop mixture or multiple cropping which is the growing of more than one type of crop in a particular piece of land in one year is a practice commonly associated with small farm holders in the tropics (Akobundu 1987) and the most practiced among the various forms of multiple cropping is the inter-cropping, which simply means growing two or more crops simultaneously with no distinct row arrangement (Rai et al; 2006). Inter-cropping had been reported to increase crop diversity, biological stability of the ecosystem and labor efficiency (Okigbo, 1977). The system ensures yield stability (Onwueme and Sinha, 1991) efficient utilization of Sunshine and land and in maintaining the fertility of the soil as well as improvement of the economic status of the farmer. The combination of groundnut with other crops range from its contribution to the sustainability of mixed cropping system and significant reduction in weed population density, as some of the cover crops are capable of smothering weeds (Abe, 2006, Atilola, 2007), to minimizing excessive water evaporation from the soil, reducing run off and erosion (Nwokwo, 2005). A good cover is an extremely essential part of the soil conservation program in the tropics (Antior, 2005, Bantu, 2007). Hence groundnut as a cover crop helps in protecting the soil, as well as enriching it (Catin, 2004, Antior 2005, Lizz, 2007). As cover crops intercept rain drops, reducing the Volume and erosive power of falling rain, with resultant decrease in the incidence of soil loss or erosion and provide suitable soil conditions for soil organisms.

Groundnut production in Sole cropping has been a common practice in the Northern part of the country in Nigeria due to availability of land, but in the South East especially Enugu State (precisely Enugu east local government area), the production of groundnut is being hampered by the scarcity of land caused by conversion of available land into residential area due to population increase and land tenure system, hence discouraged farmers to cultivate groundnut as Sole crop in large quantity. 
Thus the farmers tend to intercrop the crop with other crops as they claim it occupies large area of land and when compared with cereals or vegetable crops, the yield of groundnut in a particular space or area of land is not more profitable than the yield of maize or vegetable in the same area of land. Therefore, the essence of this study is to evaluate yield performances of groundnut in sole cropping and inter cropped with Okra and maize in Enugu state.

\section{Site location}

\section{Materials And Methods}

The experiment was conducted at the experimental farm of the department of Agricultural education, Institute of Ecumenical Education, Thinker's Corner Emene, Enugu. The area with an annual rainfall of $1200 \mathrm{~mm}-1750 \mathrm{~mm}$ is situated in South East Nigeria $\left(06^{0} 48^{1} \mathrm{~N}\right.$ and $\left.07^{0} 14^{1} \mathrm{E}\right)$. The rainfall pattern is bimodal between April and October, while dry season is between November and March. The soil is an Ultisol (FDALR, 1985) and is classified as Ustoxic Dystropept.

\section{Land Preparation \& Treatment Allocation.}

A total land area of $256.5 \mathrm{~m}^{2}(19 \mathrm{mx} 13.5 \mathrm{~m})$ was used for the experiment. The area was cleared of natural vegetation and the debris burnt. The experiment was laid out in a randomized complete block design (RCBD). There were four treatments consisting of Sole cropping of groundnut (SG), Groundnut Okra inter crop (GO), Groundnut Maize Intercrop (GM) and groundnut maize okra intercrop (GMO) with four replicates. The planting material used were seeds of Virginia groundnut variety, seeds of orba super 1 maize variety, seeds of lady finger okra variety. The seed of the groundnut in sole cropping was planted 2 seeds per hole at a spacing of $40 \mathrm{~cm} \mathrm{x}$ $25 \mathrm{~cm}$ and thinned down to one plant per hill two weeks after germination. In groundnut okra intercrop, the spacing was $60 \mathrm{~cm} \times 60 \mathrm{~cm}$, both groundnut and okra seed was planted 2 seeds per hole and thinned down one plant per stand. Groundnut maize intercrop, the planting spacing was $60 \mathrm{~cm} \times 60 \mathrm{~cm}$ and one plant per stand two weeks after germination. Groundnut/okra/maize intercrop, the spacing was $50 \mathrm{~cm} \times 50 \mathrm{~cm}$ and one plant per stand in the intercrops two weeks after germination. The experimental site was kept relatively weed free through out the period of the experiment.

\section{Data collection and analysis.}

Top soil (0-30) was collected from the study site prior before planting and analyzed in the laboratory for its nutrient content using the procedure of Black (1965). The result of the soil nutrient characteristics is given in table 1.

\begin{tabular}{|c|c|c|}
\hline Parameter & Unit & Value \\
\hline Coarse sand & $\%$ & 16 \\
\hline Fine sand & “ & 39 \\
\hline Silt & “ & 35 \\
\hline Clay & “ & 10 \\
\hline Texture & “ & Sandy loam \\
\hline $\mathrm{PH}\left(\mathrm{H}_{2} \mathrm{O}\right)$ & “ & 4.80 \\
\hline Organic matter & “ & 1.18 \\
\hline Total N & “ & 0.07 \\
\hline Avail P & $\mathrm{mg} \mathrm{kg}^{-1}$ & 3.70 \\
\hline $\mathrm{Ca}$ & $\mathrm{Cmol}+\mathrm{kg}^{-1}$ & 1.8 \\
\hline $\mathrm{Mg}$ & “ & 1.7 \\
\hline $\mathrm{Na}$ & “ & 0.18 \\
\hline $\mathrm{K}$ & “ & 0.06 \\
\hline CEC & “ & 12.6 \\
\hline
\end{tabular}

The parameters assessed were plant height, number of leaves/plant, number of branches/plant, number of days to $50 \%$ flowering and weight of pods (fruits). Data collected from the study was subjected to the analysis of variance procedure for a randomized complete block design according to Steel and Torrie (1980), LSD at 0.05 was used to compare treatment means.

\section{Result and Discussion}

The result of plant height, number of leaves and branches are shown in table 2. The groundnut/maize/okra intercrop had the least values in these parameters and intercropping system did not influence the plant height, number of leaves or the number of branches. The groundnut sole cropping recorded the highest value in these parameters when compared to the intercrops. This non significant result may be 
attributed to the competition for resources such as nutrients in the rhizosphere and light (Caballero et al, 1995, Assefa and Ledin, 2001). The shedding of groundnut plants by the maize and okra plants in this intercrop could however, contributed to the kind of result obtained. As Addo-Quaye et al, (2011) reported reduction in cop growth and net assimilation rate in maize/soybean intercrop, where maize seedlings where shaded by already established soybean. Also Willey and Osiru (1972), reported lower yield in intercropping than sole cropping due to competition.

Table 2 The effect of Sole cropping \& Intercropping of groundnut on plant height, Number of branches, Number of days to $50 \%$ flowering, Number of leaves, Weight of Pods.

\begin{tabular}{lccccc}
\hline Treatment & $\begin{array}{c}\text { Plant height } \\
\text { CM }\end{array}$ & $\begin{array}{c}\text { Number of leaves } \\
\text { per plant }\end{array}$ & $\begin{array}{c}\text { Number of Branches } \\
\text { per plant }\end{array}$ & $\begin{array}{c}\text { Number of days } \\
\text { to 50\% flowering }\end{array}$ & $\begin{array}{c}\text { weight of Pods } \\
\text { gm }\end{array}$ \\
\hline SG & 16.0 & 111.8 & 10.50 & 20.0 & 28.75 \\
GO & 14.35 & 108.5 & 9.25 & 18.0 & 22.50 \\
GM & 13.50 & 105.2 & 9.75 & 16.8 & 18.50 \\
GMO & 12.50 & 96.5 & 8.25 & 16.5 & 17.50 \\
LSD 0.05 & NS & NS & NS & 1.9 & 3.1 \\
\hline
\end{tabular}

$\mathrm{SG}=$ Groundnut Sole crop, GO= Groundnut Inter cropped with Okra, GM= Groundnut Inter cropped with maize

$\mathrm{GMO}=$ Groundnut Intercropped with maize and Okra, $\mathrm{NS}=$ none significant.

The result of number of days to $50 \%$ flowering and weight of pods presented in table 2 showed that intercropping system significantly $(\mathrm{P}=0.05)$ influenced the parameters assessed. However, the effect was not effective in the Ground nut /Okra intercrop, Ground nut / Maize intercrop and Ground nut / Maize / Okra intercrop at days to $50 \%$ flowering, since the values obtained from these intercrops are statistically similar. The values of weight of pod obtained from Ground nut / Maize intercrop and Ground nut / Maize / Okra intercrop were also similar which indicated that the effect of intercropping system were not effective in the intercrop. This agrees with the findings of Atilola (2007), who reported non-significant effect of ground nut intercropped with maize on growth and yield parameters of ground nut. The significant reduction in yield observed from the intercrop plots may be attributed to inter specific competition among the plants for space, nutrients, light, water etc. Francis et al., (1982), Pal et al., (1993), and Addo-Quaye (2011) all reported reduced intercrop yield in maize / Bean intercrop, Soybean / Maize or Soybean / Sorghum intercrop and Soybean / Maize intercrop respectively, when they investigated the effect of component density on the yield of Sorghum or Maize intercrop with Soybean or Beans.

This observation therefore suggests that the inclusion of Okra and Maize result in depression of growth and yield of groundnut. Conversely, the higher growth in plant height and yield indices as well as significant in the yield of pods suggests that groundnut thrives better on Sole cropping than intercropping. The findings agree with the work of Atilola (2007).

\section{Conclusion}

From the findings of the study, it has been observed that groundnut sole cropping performed better compared to the groundnut intercropped with Okra or Maize and the one intercropped with Okra and Maize. Nevertheless, the groundnut intercropped with Okra or Maize performed relatively well. Farmers are therefore advised to grow groundnut on sole cropping to increase yield. However, where land is scarce, farmers should intercrop groundnut with one crop either Maize or Okra to lessen Competition.

\section{References}

[1] Abe, M. O. (2006). Effect of cover-cropping on weed Population Density and Moisture Conservation in a Rice field in South Western Nigeria. Crop Science and land management 16: 58-586.

[2] Addo-Quaye, A. A. Darkwa, A. A. and Ochoo, G. K. (2011) Growth analysis of compound crops in a Maize-Soybean intercropping system as affected by time of planting and spatial arrangement. ARPN Journal of Agricultural and Biological Sciences 6(6): 34-44

[3] Akobundu 1.0 (1987). Weed Science in the tropics: Principles and Practices. John willy and Sons, Chichester PP439-448.

[4] Antoir, U. M. (2005). Studies on the influence of certain tropical legumes on Soil fertility and crop yields. Plant and Soil Science, 10: 444-448. 
[5] Assefa, G. and Ledin, I. (2001). Effect of Variety, Soil type and fertilizer on the establishment, growth, forage yield, quality and Voluntary intake by cattle of oats and vetches cultivated in pure stands and mixtures. Animal feed Sci. and Tech. 92: 95-111.

[6] Atilola, N. C. P (2007). Effect of interplant Groundnut with Maize on soil organic carbon and yield of Groundnut. Soil Fertility Research. 16: 81-86.

[7] Bantru, L. A. (2007). Maintains Soil Fertility through cover-cropping. Journal of sustainable Agriculture, 4(1): 81-85.

[8] Caballero, R. Goicoechea, E. L. and Hernaiz, P. J. (1995). Forage yield and quality of common vetch and oat Sown at Varying Seeding ratios and seeding rates of common vetch. Field Crops Res. 41: 135-140.

[9] Catin, A. O. (2004). Tropical legumes: A viable practical option for soil fertility maintenance in the tropics, Advanced Journal of Soil Science, 16: 171-177

[10] Encyclopedia of Agricultural Science (1994) Vol. 3 Academic press.

[11] Francis, C. A. Prager, M. and Tejada G. (1982). Effect of relative planting dates in bean (Phaseolus Vulgaris L.) and Maize (Zea mays L.) intercropping patterns. Field crops Res. 4: 313-320.

[12] Nwokwo, M. C. (2005). Reducing Run-off, Soil erosion, and leaching through cover-cropping. Land management, 6: 111-116.

[13] Ogbaji, M. I. (2002). Response of Okra to Nitrogen and Potassium Fertilizer in a Southern Guinea Savanna. Journal of Sustainable Agriculture and Environment 4(1) 17-22.

[14] Okigbo, B. N. (1977). Preliminary Cassava intercropping trails. Paper presented at the $1^{\text {st }}$ National Cassava Workshop, Umudike, Nigeria $9 \mathrm{pp}$.

[15] Onwueme, I. C. and Sinha, T. D. (1991). Field Crop Production in Tropical Africa. Technical centre for Agriculture and Rural cooperation Netherlands, PP103-116.

[16] Pal, U. R. Oseni, T. O. and Norman J. C. (1993). Effect of component densities on the productivity of Soybean/Maize and Soybean/Sorghum intercrop J. Agron. Crop Sci: 170: 66-70.

[17] Rai, M., Onyenuga, Gupta, B. K. and Emery, (1991). Hand book of Agriculture. Indian Council of Agricultural Research $5^{\text {th }}$ edn, Reprinted 2006.

[18] Singh, C. Singh, P. and Singh R. (2003). Modern Techniques of raising field crops. Oxford and IBH publishing Co. PVT LTD. New Delhi Reprinted 2007.

[19] Willey R. W. and Osiru D. S. 1972 studies of mixtures of maize and beans (Phaseolus Vulgaris) with particular reference to plant population. J. Agric. Sci. 79: 517-529. 